University of Nebraska - Lincoln

DigitalCommons@University of Nebraska - Lincoln

West Central Research and Extension Center, North Platte

Agricultural Research Division of IANR

2021

Impact of maize hybrid selection on water productivity under deficit irrigation in semiarid western Nebraska

Strahinja Stepanovic

Daran Rudnick

Greg R. Kruger

Follow this and additional works at: https://digitalcommons.unl.edu/westcentresext

Part of the Agriculture Commons, Ecology and Evolutionary Biology Commons, and the Plant Sciences Commons

This Article is brought to you for free and open access by the Agricultural Research Division of IANR at DigitalCommons@University of Nebraska - Lincoln. It has been accepted for inclusion in West Central Research and Extension Center, North Platte by an authorized administrator of DigitalCommons@University of Nebraska Lincoln. 


\title{
Impact of maize hybrid selection on water productivity under deficit irrigation in semiarid western Nebraska
}

\author{
Strahinja Stepanovic, ${ }^{1}$ Daran Rudnick, ${ }^{2}$ and Greg Kruger $^{1}$
}

\author{
1 West Central Research, Extension and Education Center (WCREEC), \\ University of Nebraska-Lincoln, 402W State Farm Road, North Platte, NE, USA \\ 2 Irrigation Management Specialist, 247 L.W. Chase Hall, Lincoln: \\ East Campus, Lincoln, NE, USA \\ Corresponding author — S. Stepanovic, strahinja.stepanovic@unl.edu \\ Email: D. Rudnick, daran.rudnick@unl.edu ; G. Kruger, greg.kruger@unl.edu
}

\begin{abstract}
The future economic and agricultural sustainability of semiarid western Nebraska will largely depend on more efficient utilization of the declining groundwater resources. The scope of this research was to evaluate the maize hybrid yield, water productivity (WP; i.e. grain yield produced per unit of water consumed), and irrigation water productivity (IWP; i.e. increase in grain yield per unit of irrigation water applied) across a range of semiarid climatic conditions (i.e. drought, normal, and wet) and irrigation treatments. Total of 13 maize hybrids were evaluated under full irrigation (FI), deficit irrigation (DI, receiving $~ 50 \%$ less irrigation water than FI), and dryland (DRY; rainfall only) at the University of Nebraska-Lincoln Brule Water Laboratory near Brule, Nebraska, in 2011 and 2012 and Bayer's Gothenburg Water Utilization Learning Center near Gothenburg, Nebraska, in 2010 and 2011 (i.e. four site-years). Compared to FI, DI caused yield reduction of as much as $33 \%$ in a dry, $11 \%$ in a normal, and $2 \%$ in a
\end{abstract}

Published in Agricultural Water Management 244 (2021) 106610

doi:10.1016/j.agwat.2020.106610

Copyright (C) 2020 Elsevier B.V. Used by permission.

Submitted 30 July 2020; revised 13 October 2020; accepted 23 October 2020; published 11

November 2020. 
wet year, resulting in consequently $22-47 \%$ improvement in IWP. Depending on siteyear and irrigation level, a difference of up to $7.2 \mathrm{t} \mathrm{ha}^{-1}, 3.6 \mathrm{~kg} \mathrm{~m}^{-3}$, and $5.9 \mathrm{~kg} \mathrm{~m}^{-3}$ was observed in yield, WP, and IWP, respectively, as a consequence of hybrid selection, with few top-performing hybrids yielding similarly under DI and FI in a normal and/or wet year. This study highlights the impact hybrid selection and DI have on crop water productivity (WP) and IWP as well as provides insight into strategies that can maintain productivity and profitability in water limited environments.

Keywords: Groundwater depletion, Irrigation pumping regulations, Drought tolerance, Genetic $\times$ environment $\times$ management $(G \times E \times M)$, Yield variability

\section{Introduction}

Over the past several decades, irrigation has become a crucial factor for agricultural production and a major contributor to the economy of Nebraska. According to Nebraska Policy Institute, the estimated net economic impact due to irrigated agriculture ranges from $\$ 3.6$ to $\$ 4.5$ billion (Lamphear, 2003), and it may reach up to $\$ 7.1$ billion in a years of severe drought (Nebraska Farm Bureau, 2012). Adding approximately $50 \%$ to the annual state government budget, irrigation considerably reduces the economic risk during the years of drought, providing less variability in crop yields and a stable income for both farmers and related agribusinesses (Lamphear, 2003; Nebraska Farm Bureau, 2012). The undesirable effect of this economic success has been a gradual decline in groundwater levels in some areas of the Ogallala aquifer, the largest and most valuable irrigation water source in Nebraska (Haacker et al., 2016). Groundwater pumping for irrigation created a large deficit between the discharge and recharges causing water storage in the Ogallala aquifer to decline approximately $410 \mathrm{~km}^{3}$ since 1935 (Haacker et al., 2016). With groundwater levels continuing to decline in most areas of the Ogallala aquifer (McGuire, 2017), maintaining economic and agricultural sustainability in Nebraska and the High Plains region will largely depend on more efficient utilization of the available water resources (Lilienfeld and Asmild, 2007; Rudnick et al., 2019).

Maize (Zea mays L.) is the most abundant irrigated crop in Nebraska occupying approximately 2.6 million ha or $70 \%$ of irrigated lands; thus, improving efficiency of irrigation water use in maize production may lead to significant improvements in preventing further decline in groundwater supply (Kranz et al., 2008). Knowing the volume of water 
stored in the soil profile and the long-term annual precipitation averages amount of effective rainfall during the growing season, an approximate irrigation requirements can be estimated for the region to assess the crops evapotranspiration (ET) demand and avoid excessive yield penalties (Lilienfeld and Asmild, 2007; Kranz et al., 2008). In semiarid regions, like western Nebraska, a combination of low seasonal rainfall ( 200-400 mm), light texture soils, low soil organic matter, high velocity winds, and low relative humidity can substantially increase seasonal crop ET demand (Payero et al., 2008). Other factors such as groundwater pumping regulations, load management, and/or low well capacities often limit the amount of water available for irrigation and negatively impact crop yield and profitability (English, 1990; Payero et al., 2008; Rudnick et al., 2019). Simulation analysis by Grassini et al. (2011) showed that improving irrigation application and system efficiencies as well as irrigation management strategies can save up to $32 \%$ of irrigation water allocated to maize production in Western U.S. Corn Belt while causing minimum yield penalties. While these projections are promising, a cropping-system approach to water conservation that includes integration of hybrid selection, crop rotations, planting arrangements, no-till and other agronomic practices needs to be implemented to sustain the declining groundwater resources (Van Duivenbooden et al., 2000).

Deficit irrigation has been investigated as a valuable strategy to increase the efficiency of applied irrigation water and improve the management of available water resources in semiarid climates around the world (Stewart et al., 1983; Oweis et al., 1998; Xue et al., 2003; Payero et al., 2008; Yenesew and Tilahun, 2009; Rudnick et al., 2019). Deficit irrigation is commonly defined as an optimization strategy in which irrigation is applied below the crop ET demand to balance grain yield, net profitability, and the amount of water available (Rudnick et al., 2019). In a semiarid climate, the most common deficit irrigation strategy is to avoid water stress during the drought-sensitive growth stages (e.g. early reproductive) and withhold irrigation during the drought-tolerant growth stages (e.g. vegetative or later reproductive) (Geerts and Raes, 2009). While deficit irrigation can inevitably lead to drought stress it can also reduce water losses via evaporation, runoff, and percolation with minimal yield penalty (Grassini et al., 2011). Consequently, deficit irrigation is often targeted to stabilize yields and increase crop water productivity rather than maximizing yield (Geerts and Raes, 2009). 
Other advantages of deficit irrigation may include: (1) decrease in risk of fungal diseases due to less humidity in the crop canopy (Cicogna et al., 2005; Marouelli and Silva, 2007), (2) reduce the leaching of nutrient bellow the root zone consequently lowering the fertilizer needs and improving groundwater quality (Ünlü et al., 2006), (3) maintaining or improving grain quality (Fabeiro, 2001; Ertek and Kara, 2013), (4) and increasing profitability (English, 1990). Depending on the growing season conditions, available water resources, as well as management approach in terms of production inputs, yield goal, efficiency and profitability, deficit irrigation may not always be the right approach. Nevertheless, in areas where deficit irrigation is practiced regularly, it is very important to consider the additional management practices that can increase effectiveness (Oweis et al., 1998; Rudnick et al., 2019). For more information on deficit irrigation strategies and their impact on crop yield and groundwater movement in US High Plains we refer readers to Rudnick et al. (2019).

Hybrid selection is another decision making strategy of great importance in maize production, particularly in drier environments where maize susceptibility to water stress varies considerably by genotype (Lorens et al., 1987; Atteya, 2003; Kaman et al., 2011; Moradi et al., 2012; Aydinsakir et al., 2013; Sabagh et al., 2015; Al-Naggar et al., 2016; Sabagh et al., 2018). Maize response to water stress is regulated by many genes that control important physiological (cellular) and morphological (whole plant) processes (Campos et al., 2004). Identification and selection of morpho-physiological traits such as enhanced stomatal conductance, reduced anthesis-silking interval (ASI), increased root-shoot ratio, etc. has helped breeders develop hybrids that perform better under water-stressed conditions (Atteya, 2003; Moradi et al., 2012; Aydinsakir et al., 2013; Hao et al., 2015a, 2015b; Al-Naggar et al., 2016; Sabagh et al., 2018). The expression of those genes depend on timing and severity of drought as well as complex genotype $\mathrm{x}$ environment ( $\mathrm{G} \times \mathrm{E}$ ) and gene $x$ gene (epistasis) interactions (Campos et al., 2004). Finding the ideal hybrid for a particular region can be a challenging task, especially in the semiarid High Plains where combination of low moisture and high elevation cause large variations in daily temperatures and weather patterns are very unpredictable (Guillen-Portal et al., 2003). According to Guillen-Portal et al. (2003) the ideal hybrid for this region must perform well across the range of environments. This is often not the objective of 
many breeding and hybrid-testing programs that focus more on selecting genotypes that perform well in the extreme dry and/or very productive environments. More information is needed on hybrid performance under deficit or limited irrigation conditions.

Increased productivity of maize under deficit irrigation throughout the semiarid environments of the High Plains and other parts of the world is imperative (Geerts and Raes, 2009; Yenesew and Tilahun, 2009; Aydinsakir et al., 2013; Al-Naggar et al., 2016; Rudnick et al., 2019), but deficit irrigation alone may not always lead to an increase in water use efficiency (Eck, 1986; Payero et al., 2008; Rudnick et al., 2019). In a semiarid environments where water supply is limited, hybrid selection can be a great complementary piece and more likely to increase yield, and consequently water use efficiency and profitability of the cropping system. Studying differences between drought tolerant and conventional hybrids in Texas High Plains, Hao et al. (2015b) found much as $24 \%$ increase in yield and $30 \%$ increase in water use efficiency when droughttolerant hybrid was grown under deficit irrigation. The objective of this study was to evaluate yield, water productivity (WP; i.e. grain yield produced per unit of water supply), and irrigation water productivity (IWP; i.e. increase in grain yield per unit of irrigation water applied) of maize hybrids under dryland, deficit irrigation, and full irrigation conditions in semiarid environment of western Nebraska.

\section{Materials and methods}

\subsection{Site description}

Field experiments were conducted at the University of Nebraska-Lincoln West Central Water Resources Field Laboratory near Brule, Nebraska (GPS coordinates $41.130225^{\circ} \mathrm{N}, 101.972297^{\circ} \mathrm{W}$ ) in 2011 and 2012 and at Bayer's Gothenburg Water Utilization Center near Gothenburg, Nebraska (GPS coordinates $40.886211^{\circ} \mathrm{N}, 100.159268^{\circ} \mathrm{W}$ ) in 2010 and 2011. The predominant soil type at Brule was Kuma silt loam (Finesilty, mixed, superactive, mesic Pachic Argiustolls) with 0-1\% slopes, average water content at field capacity of $0.29 \mathrm{~m}^{3} \mathrm{~m}^{-3}$ and at wilting point of $0.13 \mathrm{~m}^{3} \mathrm{~m}^{-3}, 1.3 \%$ soil organic matter, and soil $\mathrm{pH}$ of 7.0 . The predominant soil type at Gothenburg was Hord silt loam (Fine-silty, mixed, 
superactive, mesic Cumulic Haplustolls) with 0-1\% slopes, average water content at field capacity of $0.21 \mathrm{~m}^{3} \mathrm{~m}^{-3}$ and at wilting point of 0.11 $\mathrm{m}^{3} \mathrm{~m}^{-3}, 3.2 \%$ soil organic matter and soil $\mathrm{pH}$ of 6.8 . The experiments at Brule site were placed under a variable rate center pivot irrigation system (model RPM, Reinke Manufacturing Co, Deshler, Nebraska). Water for the system was pumped from the Ogallala aquifer, using an electric turbine pump with a capacity of 38 liters per second (600 gallons per minute) at $483 \mathrm{kPa}$ of pressure. At Gothenburg site, water was applied using a subsurface drip irrigation (SDI) system installed at $30 \mathrm{~cm}$ depth with $100 \mathrm{~cm}$ centers. The system had capacity to apply $2.54 \mathrm{~cm}$ of water in $24 \mathrm{~h}$ time period. At both sites, maize was grown in rotation with soybean using no-till planting techniques.

\subsection{Experimental design and treatments}

The experiments were conducted using a split plot design with 4 replications at Brule and 3 replications at Gothenburg. The whole-plot consisted of three irrigation treatments (i.e. irrigation blocks) including full irrigation (FI), deficit irrigation (DI), and dryland (DRY), while the subplots were 13 maize hybrids. The irrigation scheduling for FI was managed by maintaining soil available water between field capacity and the pre-determined allowable soil water depletion level $(\sim 40 \%$ of the field capacity) at which there is no water stress to the crop. The DI treatment received approximately 50\% less water than FI (49-53\% depending on site-year; Table 1), achieved either by decreasing the irrigation frequency across treatments or applying a percentage of full irrigation during each irrigation event. The objective of DI was not to evaluate the effects of pre-determined level of water stress on the crop, but rather to impose some level of water stress across all hybrids and observe the rage of hybrid responses. The DRY was completely dependent on rainfall. After crop emergence, aluminum access tubes were installed for one hybrid in each fully irrigated block (assuming minimal differences in soil water extraction between hybrids). Soil volumetric water content was measured weekly using a neutron probe method to a depth of $120 \mathrm{~cm}$ in $30 \mathrm{~cm}$ increments starting from the soil surface (Evett and Steiner, 1995). In addition, modified atmometer (ET gauge) and crop coefficients were used to estimate the crop ET (Irmak et al., 2005). Decision to irrigate was based on the assessment of the available soil water (i.e. neutron 
probe readings), crop water demand at the given growth stage, and 10day weather/rain forecast. A minimum $30 \mathrm{~m}$ buffer zones were used at Brule site to separate the irrigation treatment. The buffer zones for SDI system at Gothenburg were $3 \mathrm{~m}$ (i.e. four maize rows). The amount, frequency and timing of rainfall and irrigation varied depending on year and site and is summarized in Table 1. Within each irrigation block, 13 maize hybrids were planted into $3 \mathrm{~m}$ wide by $10 \mathrm{~m}$ long plots using a 4-row planter (Almaco Seed Pro, Nevada, Iowa) with $76 \mathrm{~cm}$ row spacing. The maize hybrids' relative maturity, drought tolerance and other agronomic characteristics are summarized in Table 2.

\subsection{Cultural practices}

Maize at Brule was planted on 23 May 2011 and 16 May 2012. At Gothenburg, maize was planted on 1 May 2010 and 3 May 2011 in 2010 and 2011. Seeding rates were 80,000 seeds ha ${ }^{-1}$ for DI and FI, while DRY treatment was seeded at 52,000 seeds ha- ${ }^{-1}$. Lower seeding rate under DRY was implemented to reflect common agronomic practice for the region. Herbicide program at Brule included pre-emergence/burndown application of Harness Xtra 5.6 l (Monsanto, St. Louis, MO, USA) with RoundUp WeatherMAX (Monsanto, St. Louis, MO, USA) at planting and another post-emergence application of RoundUp WeatherMAX at V5V10 maize. At Gothenburg, weeds were controlled by applying tank mixture of Degree Xtra (Monsanto, St. Louis, MO, USA) and RoundUp WeatherMAX shortly after planting along with post-emergence application of RoundUp WeatherMAX at V5-V10 maize. Soil samples were collected at each site at depths of $0-20 \mathrm{~cm}$ and $20-60 \mathrm{~cm}$ in the spring before planting (mid-April) and analyzed for $\mathrm{pH}$, soluble salts, organic matter, available nitrate- $\mathrm{N}\left(\mathrm{NO}_{3}-\mathrm{N}\right)$, phosphorus $(\mathrm{P})$, and potassium (K). Soil nutrient levels (excluding $\mathrm{NO}_{3}-\mathrm{N}$ ) were above sufficiency levels, and soil $\mathrm{pH}$ in the top $20 \mathrm{~cm}$ was in a desirable range at both sites (Shaver, 2014). To ensure uniform soil fertility levels across treatments plots received preplant application on anhydrous ammonia at $110 \mathrm{~kg} \mathrm{ha}^{-1}$ of $\mathrm{N}$ rate and V3V8 drop nozzle application of $100 \mathrm{~kg} \mathrm{ha}^{-1}$ of $\mathrm{N}$ rate in from of urea ammonium nitrate (32-0-0). Maize plots at Brule were harvested on 17 Nov in 2011 and on 14 Nov in 2012, while maize harvest occurred on 15 Oct in 2010 and on 4 Oct 4 in 2011 at Gothenburg. 


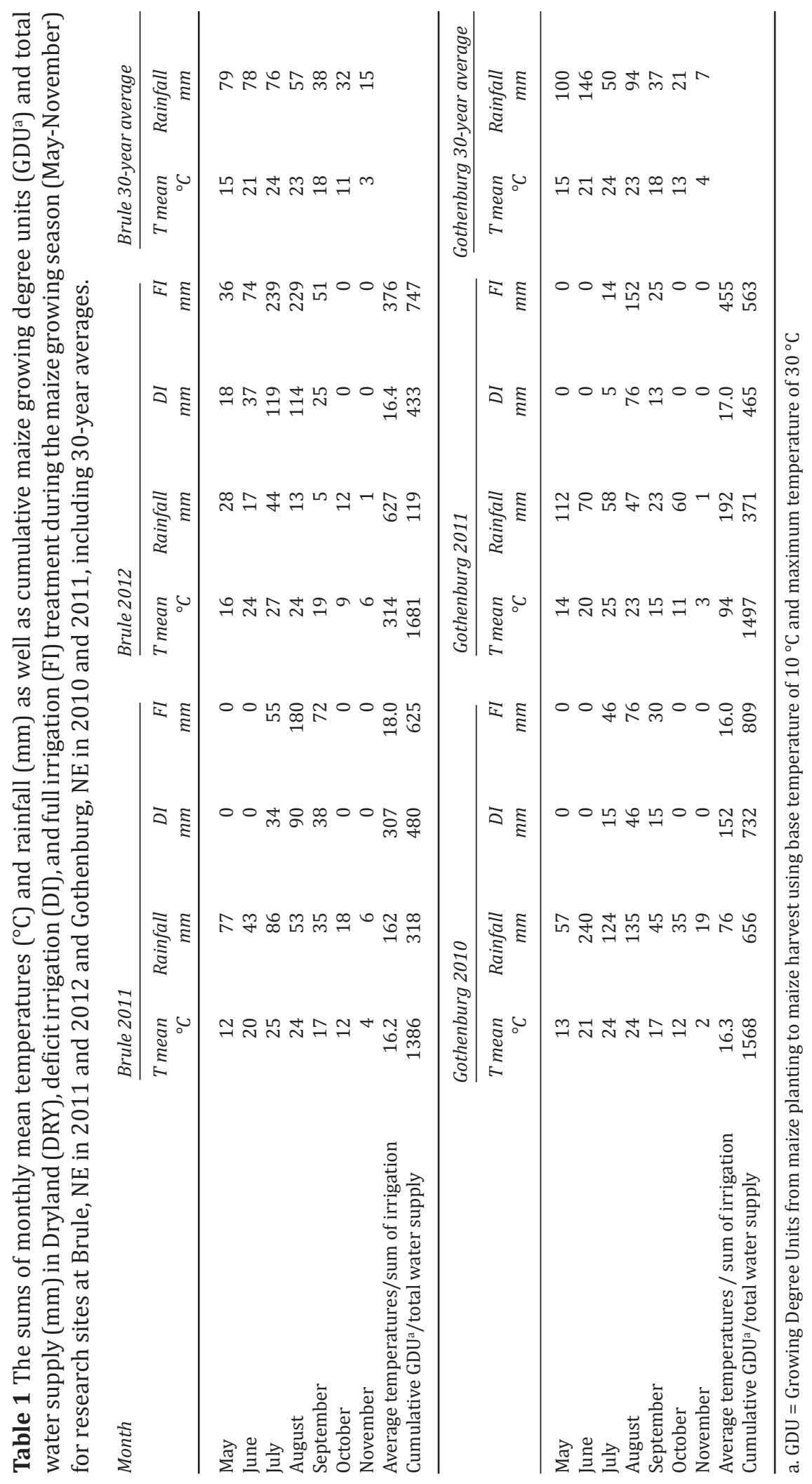




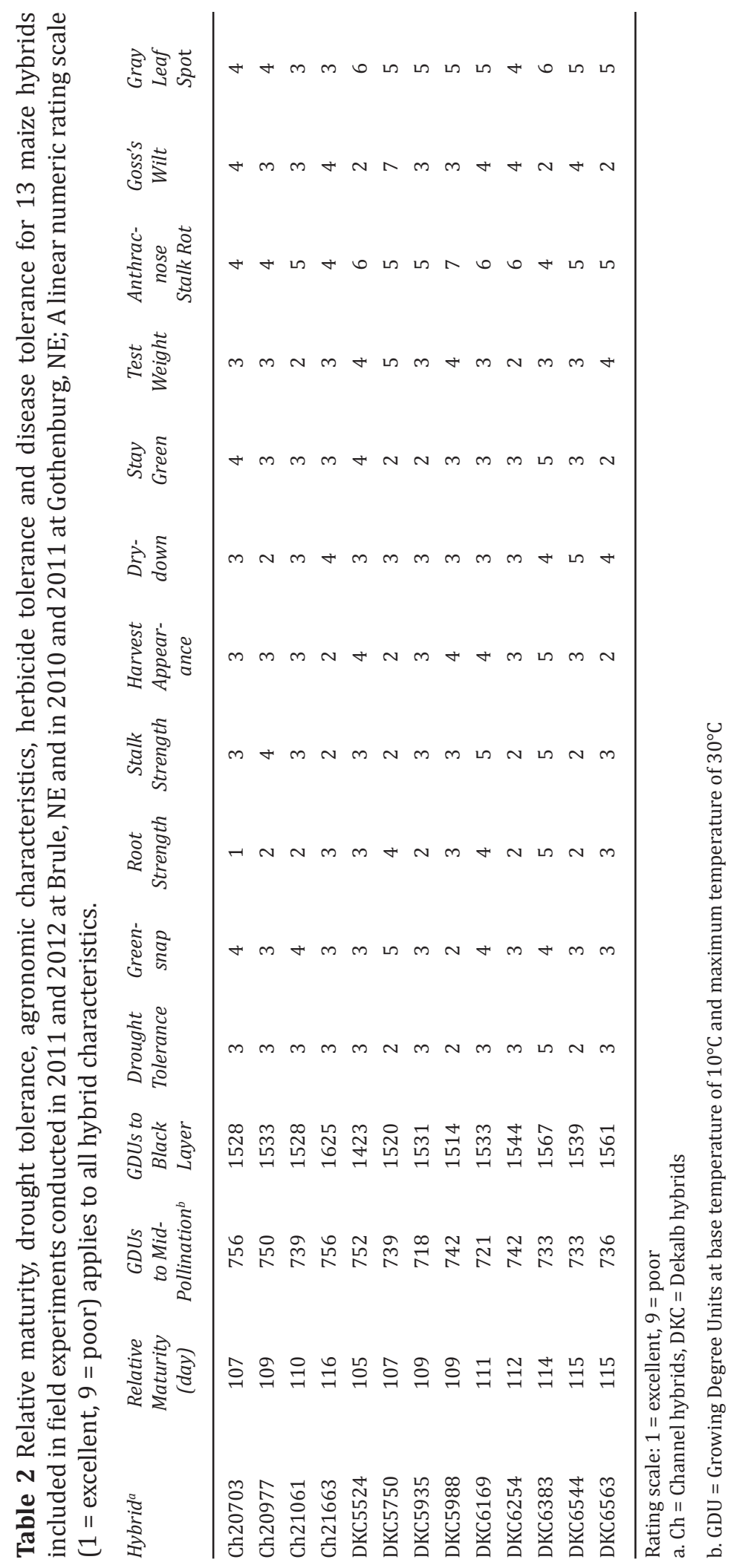




\subsection{Data collection and statistical analysis}

The center two rows of each plot were harvested for grain yield using a plot combine. Grain moisture at harvest was recorded and yields were adjusted to $15.5 \%$ grain moisture content for the comparison. Water productivity (WP; $\mathrm{kg} \mathrm{m}^{-3}$ ) and irrigation water productivity (IWP; $\mathrm{kg}$ $\left.\mathrm{m}^{-3}\right)$, as suggested by Bos $(1980,1985)$, indices were calculated for each irrigation by maize hybrid treatment combination using the following equations:

$$
\begin{aligned}
& W P=Y /\left(R+I_{i}\right) \\
& I W P=\left(Y_{h i}-Y_{D R Y}\right) / I_{i}
\end{aligned}
$$

where $Y=$ yield $\left(\mathrm{g} \mathrm{m}^{-2}\right), Y_{h i}=$ yield of $h^{\text {th }}$ maize hybrid for the $i^{\text {th }}$ irrigation treatment (mm), $Y_{D R Y}=$ average DRY yield $\left(\mathrm{g} \mathrm{m}^{-2}\right)$ across all maize hybrid at a given site-year, $R=$ seasonal rainfall $(\mathrm{mm})$, and $I_{\mathrm{i}}=$ irrigation depth for the $\mathrm{i}^{\text {th }}$ irrigation treatment $(\mathrm{mm})$. To allow for a practical application of hybrid IWP values irrigated yield of a hybrid was compared to the average DRY yield across all hybrids. This eliminated the confounding effect of miss-interpreting high IWP values as a positive trait solely because hybrid yielded below-average under DRY; and vice-versa, miss-interpreting low IWP as a negative trait solely because particular hybrid had above-average DRY yield. Therefore, average DRY yield was used as a benchmark to which irrigated yields of individual hybrids were compared.

All evaluated parameters (crop yield, WP, and IWP) were subjected to analysis of variance (ANOVA) using PROC GLIMMIX procedure of the Statistical Analysis System (SAS) and the residuals were tested for the assumptions of normality and homogeneity of variances with PROC UNIVARIATE procedure (SAS Institute, 2013). The site-years, irrigation treatments, maize hybrids and their interactions were treated as fixed effects, while the effects of replication nested within site-years and irrigation blocks (whole-plot) nested within replication were treated as random effects. Means for the significant treatment effects were compared using Fisher's protected least significant difference (LSD) procedure at $\mathrm{P}<0.05$. 


\section{Results}

\subsection{Weather conditions}

At Gothenburg-2010 seasonal rainfall was $656 \mathrm{~mm}$ which was 44\% greater than the 30-year average (Table 1). Typical rainfall patterns of semiarid west-central Nebraska (i.e. 250-500 mm) were observed at Brule-2011 and Gothenburg-2011, while severe drought conditions (i.e. $119 \mathrm{~mm}$ of seasonal rainfall) occurred at Brule-2012 (Table 1). At all siteyears, irrigation scheduling was intensified, and depth of application increased when maize was in the reproductive stage (i.e. Jul-Sep) and high in water demand (Table 1). At Gothenburg-2010 (wet year), irrigations were applied more frequently and with lighter irrigation amounts due to above-normal rainfall and good soil moisture conditions throughout the growing season. At Brule-2011 and Gothenburg-2011, more than $60 \%$ of total irrigation water was applied in a typically dry month $\mathrm{Au}-$ gust (Table 1). At Brule-2012 some irrigation water was applied in May and June due to severe drought conditions during crop germination and vegetative growth and development (Table 1). A late season windstorm (Oct 6) caused significant harvest loss at Gothenburg- 2011 due to lodging and heavy ears dropping from the stalks. Based on hourly data from the local weather station, the wind speed during the 0ct 6th windstorm at Gothenburg-2011 exceeded $8.9 \mathrm{~m} \mathrm{~s}^{-1}$ between 11:00 am and 11:00 pm and was $>13.4 \mathrm{~m} \mathrm{~s}^{-1}$ between 5:00 $\mathrm{pm}$ and 9:00 pm, reaching maximum wind speed of $15.2 \mathrm{~m} \mathrm{~s}^{-1}$ (wind gusts likely higher than $15.2 \mathrm{~m} \mathrm{~s}^{-1}$ hourly average). The ear drop evaluated visually in each irrigation treatment as a percent ear/yield loss was 5\%, 25\%, and 40\% in DRY, DI, and FI treatment, respectively. The dropped ears were considered non-harvestable, while the remaining ears (i.e. ears still on a maize plant) were machine harvested for yield and presented in this manuscript.

\subsection{Irrigation effects on yield, wp, and IWP}

Yield response to irrigation treatments varied between environments (Table 3; site-year by irrigation interaction significant). In general, the increase in seasonal rainfall resulted in higher dryland yield, lower need for supplemental irrigation water, and smaller yield differences between the irrigation treatments. During the 2012 drought at Brule $(119 \mathrm{~mm}$ 
Table 3 Analysis of variance (ANOVA; 0.05 P level) for Yield ( $\mathrm{ha}^{-1}$ ), Water productivity (WP; $\mathrm{kg} \mathrm{m}^{-3}$ ), and Irrigation water productivity (IWP; $\mathrm{kg} \mathrm{m}-3$ ) as affected by site-year (SY), irrigation (I), and hybrid (H). The significance levels of the effects of irrigation (I) and hybrid (H) on Yield, WP, and IWP at four site-years including Brule-2011, Brule-2012, Gothenburg-2010, and Gothenburg-2011.

\begin{tabular}{|c|c|c|c|}
\hline Effect & Yield & $W P$ & $I W P$ \\
\hline \multicolumn{4}{|c|}{ Across all site-years } \\
\hline Site-Year (SY) & *** & $* * *$ & $* * *$ \\
\hline Irrigation (I) & *** & $* * *$ & *** \\
\hline Hybrid $(\mathrm{H})$ & *** & $* * *$ & *** \\
\hline $\mathrm{SY} \times \mathrm{I}$ & *** & $* * *$ & *** \\
\hline $\mathrm{SY} \times \mathrm{H}$ & *** & $* * *$ & $* * *$ \\
\hline $\mathrm{I} \times \mathrm{H}$ & ns & ns & $* * *$ \\
\hline $\mathrm{SY} \times \mathrm{I} \times \mathrm{H}$ & ns & * & $* * *$ \\
\hline \multicolumn{4}{|l|}{ Brule-2011 } \\
\hline I & *** & *** & $* * *$ \\
\hline $\mathrm{H}$ & *** & $* * *$ & *** \\
\hline $\mathrm{I} \times \mathrm{H}$ & ns & ns & *** \\
\hline \multicolumn{4}{|l|}{ Brule-2012 } \\
\hline I & *** & * & * \\
\hline $\mathrm{H}$ & *** & *** & $* *$ \\
\hline $\mathrm{I} \times \mathrm{H}$ & ns & ns & ns \\
\hline \multicolumn{4}{|c|}{ Gothenburg-2010 } \\
\hline I & *** & *** & * \\
\hline $\mathrm{H}$ & *** & *** & ** \\
\hline $\mathrm{I} \times \mathrm{H}$ & ns & $*$ & * \\
\hline \multicolumn{4}{|c|}{ Gothenburg-2011 } \\
\hline I & *** & $* * *$ & ns \\
\hline $\mathrm{H}$ & $* * *$ & $* * *$ & $* * *$ \\
\hline $\mathrm{I} \times \mathrm{H}$ & ns & ** & $* *$ \\
\hline
\end{tabular}

ns $=$ not significant; ${ }^{*} \mathrm{P}<0.05 ;{ }^{* *} \mathrm{P}<0.01 ;{ }^{* * *} \mathrm{P}<0.001$

of seasonal rainfall), DRY yield was only $1.6 \mathrm{t} \mathrm{ha}^{-1}$ and high amounts of irrigation water were applied (314 $\mathrm{mm}$ in DI and $627 \mathrm{~mm}$ in FI) to increase the yield to $7.1 \mathrm{t} \mathrm{ha}^{-1}$ under DI and $10.6 \mathrm{t} \mathrm{ha}^{-1}$ under FI (Table 1, Fig. 1). In contrast, above-average seasonal rainfall at Gothenburg-2010 (656 $\mathrm{mm}$ ) produced exceptional dryland yield of $15.3 \mathrm{t} \mathrm{ha}^{-1}$, the need for supplemental irrigation was reduced to $76 \mathrm{~mm}$ and $152 \mathrm{~mm}$ for DI and FI, respectively, and yield increase over DRY was 1.1 and $1.5 \mathrm{t} \mathrm{ha}^{-1}$, respectively. (Table 1, Fig. 1). With the exception of Gothenburg-2011, where the wind storm caused significant harvest losses, the yield gap between DRY and DI was greater than the yield gap between DI and FI at all other sites, despite the same incremental increase in the applied 
irrigation water (Fig. 1). The yield gap between the irrigation treatments narrowed at site-years that received more seasonal rainfall (Fig. 1). For example, the yield gap at Brule-2012 (drought year), Brule-2011 (normal year), and Gothenburg-2010 (wet year) was, respectively, 5.5, 5.1, and $1.1 \mathrm{t} \mathrm{ha}^{-1}$ between DRY and DI, and 3.5, 1.5, and $0.5 \mathrm{t} \mathrm{ha}^{-1}$ between DI and FI (Fig. 1). On a percentage scale, yield reduction in DRY compared to DI was $77 \%, 42 \%$, and $7 \%$ in a drought, normal, and wet year, respectively; while yield reduction in DI compared to FI was 33\%,11\%, and $2 \%$ in a drought, normal, and wet year, respectively.

Irrigation significantly affected WP at all site-years (Table 3). Increase in total water supply (rain + irrigation) decreased WP, with a few exceptions (Fig. 1). Among the three irrigation treatments, FI had the lowest WP at all site-years, while DI had lower WP than DRY at two out of four site-years (Fig. 1). Compared to FI, WP under DI increased by 15\%, 20\%, 8\%, and 18\% at Brule-2012 (drought year), Brule-2011 (normal year), Gothenburg-2010 (wet year), and Gothenburg-2011 (normal year), respectively (Fig. 1). When averaged across all site-years DI and DRY had similar WP, but decrease in seasonal rainfall led to a relative increase in WP under DI. Compared to DRY, WP under DI was $12.5 \%$ higher $(0.2$ $\mathrm{kg} \mathrm{m}^{-3}$ ) in a drought year (i.e. Brule-2012), similar in a normal year (Brule-2011), and 4\% lower in a wet year (Gothenburg-2010). At Gothenburg-2011, wind storm caused significant yield losses under DI and FI, possibly due to heavier ears being more prone to ear-drop. Irrigation had no effect on yield and DRY treatment resulted in 19\% and 30\% greater WP than DI and FI, respectively (Fig. 1).

Among four site-years, the highest IWP was obtained at Brule-2011 (3.2 $\mathrm{kg} \mathrm{m}^{-3}$ under DI and $2.1 \mathrm{~kg} \mathrm{~m}^{-3}$ under FI) in a year with the average seasonal rainfall, while lower IWP was observed in a drought (i.e. Brule-2012; 1.4-1.7 $\mathrm{kg} \mathrm{m}^{-3}$ ), wet season (i.e. Gothenburg-2010; $1.0-1.5 \mathrm{~kg} \mathrm{~m}^{-3}$ ), or in a season when other yield limiting factors, such wind storm, impacted harvestable yield (i.e. Gothenburg-2011; 0.6-0.7 $\mathrm{kg} \mathrm{m}^{-3}$ ). When averaged across all site-years, DI had 30\% higher IWP than FI (Fig. 1), but the relative differences in IWP between DI and FI were higher in the environments with normal (32\% at Brule-2011) and wet (32\% at Gothenburg-2010) than it was in a drought year (18\% at Brule-2012) (Fig. 1). 


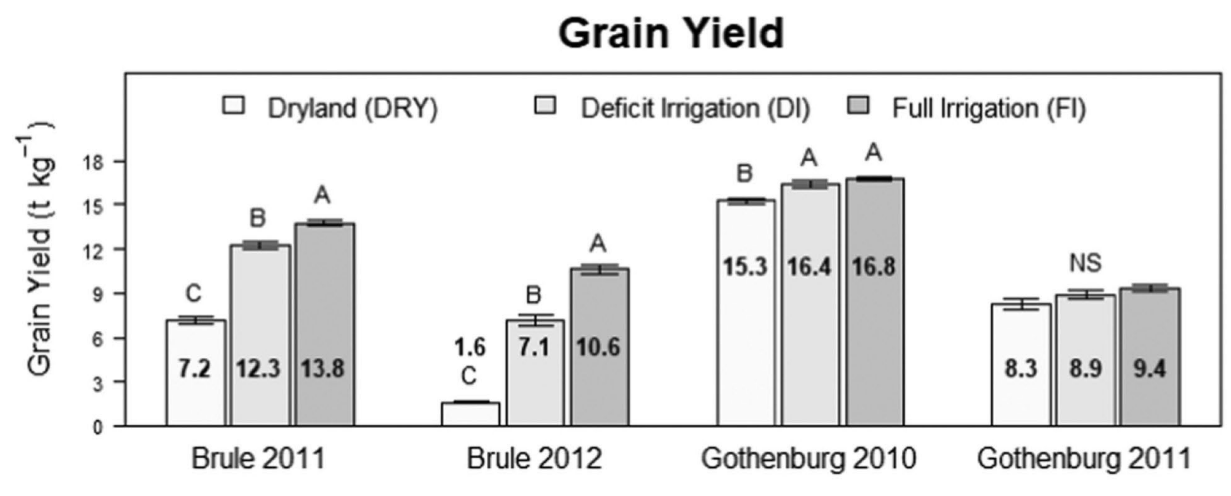

Water Productivity (WP)

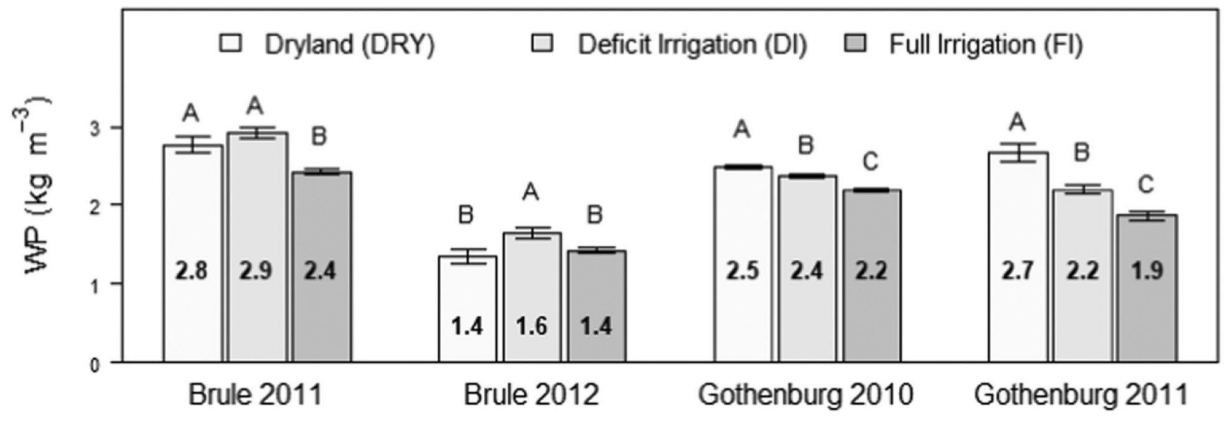

Irrigation Water Productivity (IWP)

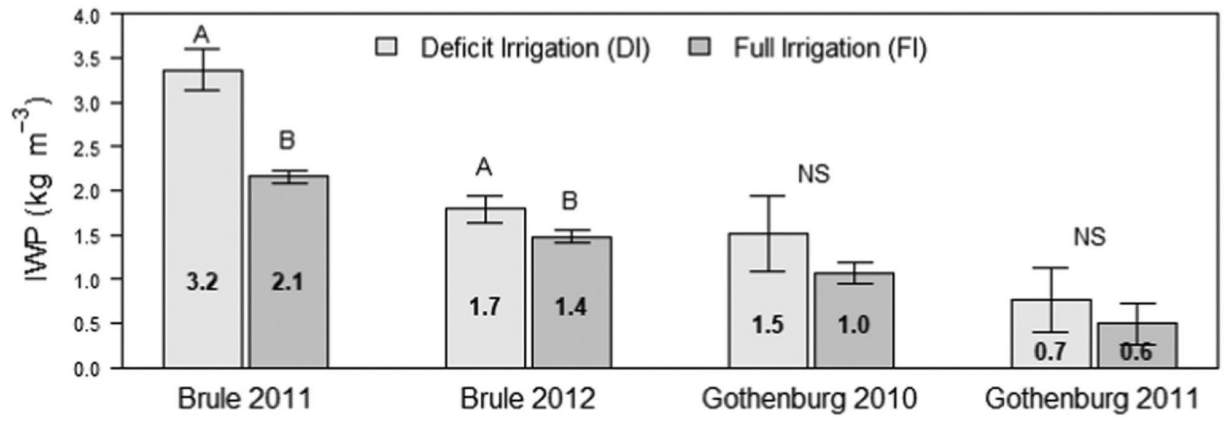

Fig. 1. Grain yield $\left(\mathrm{t} \mathrm{ha}^{-1}\right)$, Water productivity (WP; $\left.\mathrm{kg} \mathrm{m}^{-3}\right)$ and Irrigation water productivity (IWP; $\mathrm{kg} \mathrm{m}^{-3}$ ) combined over 13 maize hybrids for dryland (DRY), deficit (DI) and full irrigation (FI) treatments at Brule 2011, Brule 2012, Gothenburg 2010, and Gothenburg 2011.

\subsection{Hybrid effects on yield}

The three-way interaction between site-years, irrigation and hybrids was not significant for yield, suggesting that hybrid performance (i.e. 
hybrid ranking) was similar under different irrigation regimes regardless of the site-year (Table 3). A hybrid with the above-average yield on DRY also yielded above-average under DI and FI and vice-versa. Average yield under DRY, DI, and FI at Brule-2012 was 1.6, 7.1, and $10.6 \mathrm{t}$ $\mathrm{ha}^{-1}$, respectively. DKC6544 had the best yield performance under all irrigation treatments yielding 3.0,10.2, and $12.7 \mathrm{t} \mathrm{ha}^{-1}$ at DRY, DI, and FI, respectively (Figs. 1 and 2). Ch21633 yielded 0.7, 3.8, and 8.9 t ha $^{-1}$ at DRY, DI, and FI, respectively, which was the lowest yield compared to all other hybrids evaluated (Figs. 1 and 2). When yields were averaged across irrigation treatments, hybrid performance varied significantly by the environment (Table 3; significant site-year by hybrid interaction). In terms of yield stability (i.e., the ability of a hybrid to perform similarly across a range of environments) some hybrids performed similarly at one site (regardless of the year-to-year differences in weather conditions), while others maintained performance under similar weather conditions (regardless of the site, i.e. differences in soil types). A total of 8 hybrids, including Ch21061, Ch21633, DKC5750, DKC5935, DKC5988, DKC6166, DKC6383, and DKC6563 had similar yield rank at Brule site regardless of year (2011 and 2012), while a slightly different group of 9 hybrids, including Ch20977, Ch21061, Ch21663, DKC5524, DKC5750, DKC6169, DKC6254, DKC6544, and DKC6563 consistently performed at Gothenburg site in 2010 and 2011 (Table 4). High performing hybrids at Brule did not necessarily perform well at Gothenburg and vice-versa (Table 4). Total of 4 hybrids, including Ch20703, Ch20977, Ch21633, and DKC5988 performed consistently under similar weather conditions across two sites (Table 4). Ch20703 was ranked 1st at Brule-2011 (12.8 t ha-1) and 2nd at Gothenburg-2011 (10.0 t ha-1) when rainfall patterns were similar to longterm average, while the same hybrid under-performed in a wet year (ranked 11th at Gothenburg-2010) and drought year (ranked 9th at Brule-2012) (Table 4). Very few hybrids (total of 3 hybrids) performed consistently across all site-years. DKC6544 was a very robust and good performing hybrid at all site-years yielding 11.4, 9.2, 16.1, and $9.8 \mathrm{tha}^{-1}$ at Brule-2011, Brule-2012, Gothenburg-2010, and Gothenburg-2011, respectively. Ch21633 consistently under-performed across all site years yielding 10.6, 3.9, 15.9, and $8.1 \mathrm{t} \mathrm{ha}^{-1}$ at Brule-2011, Brule-2012, Gothenburg-2010, and Gothenburg-2011, respectively (Table 3). 

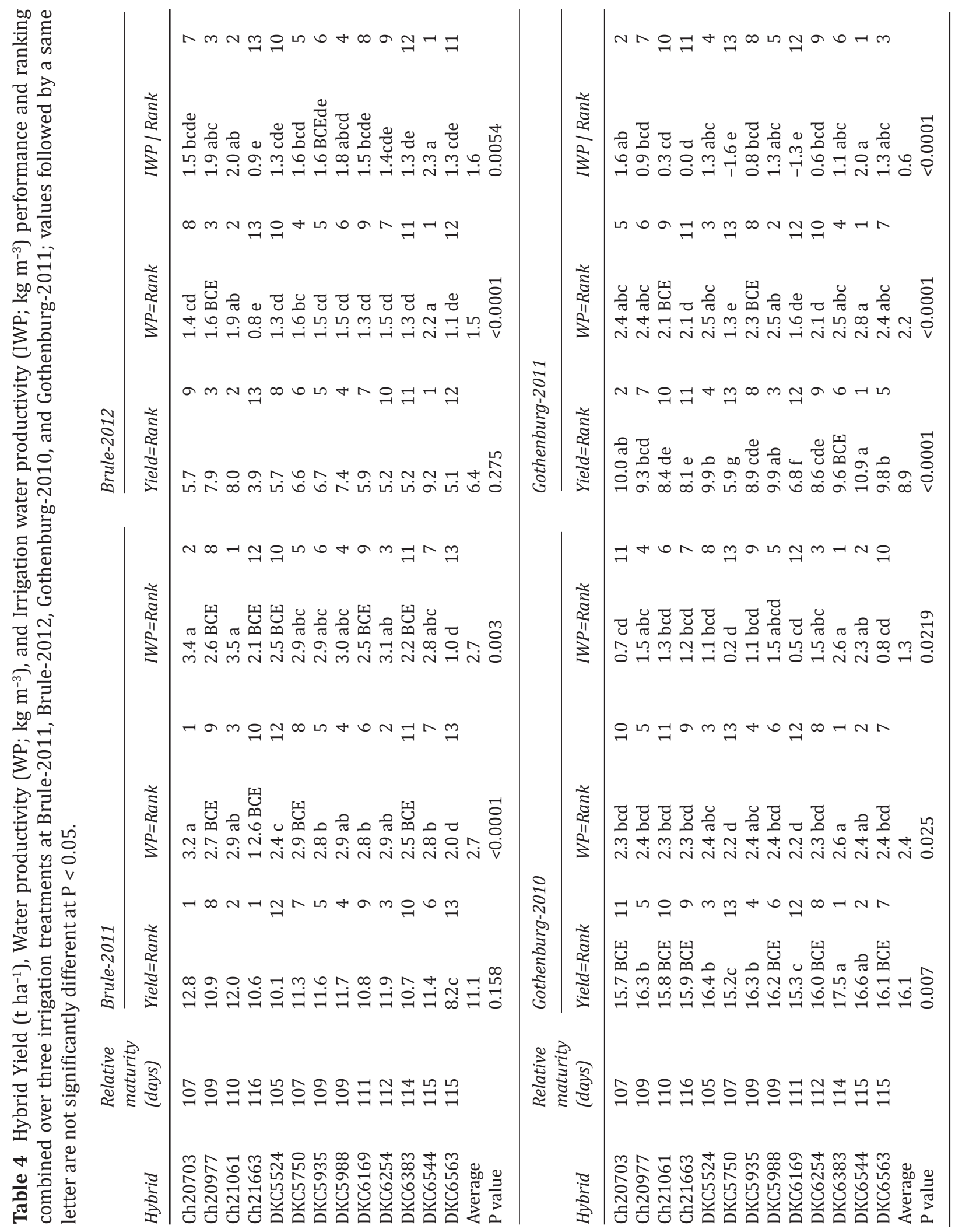
Although the overall trend indicates that irrigation did not significantly impact hybrid yield performance, there were several cases of hybrid by irrigation interaction. Fig. 2 summarizes hybrid yield responses ranked by their performance under DI and illustrates few such cases at all site-years. One example is a contrast between Ch21061 and DKC5935 at Brule-2011 (Fig. 2). The two hybrids had a similar yield under DRY (p value $=0.8373$ ) and FI ( $\mathrm{p}$ value $=0.4185)$, but Ch21061 yielded $2.3 \mathrm{t} \mathrm{ha}^{-1}$ ( $p$ value $=0.0119$ ) more than DKC5935 under DI (Fig. 2). On rare occasions, especially in the environment with high seasonal rainfall (i.e. Gothenburg-2010), irrigating a crop to full irrigation requirement led to a significant yield reduction. For example, yield of DKC6455 under DI at Gothenburg-2010 (i.e. wet year) was $1.5 \mathrm{t} \mathrm{ha}^{-1}$ higher ( $\mathrm{p}$ value $=0.0302$ ) than under FI (Fig. 2). Increased complexity of scheduling irrigation under wet conditions, such as inability to predict large rainfall events occurring shortly after irrigation events, may have contributed to root hypoxia, loss of plant available nitrogen, increase disease incidence and/or other factors, which can indirectly reduce yield (Singh et al., 2018). The data also showed that hybrids with lower yield potential (i.e. poor overall yield performance) did not respond well to DI and tended to have a larger yield gap between DI and FI then high-performing hybrids. Three such hybrids, including DKC6381, CH21663, and DKC6563 yielded well below-average under DI at both Brule-2010 and Brule-2011 (Fig. 2).

\subsection{Hybrid effects on WP and IWP}

While general trend suggests that hybrid yield performance was similar under different irrigation treatments within each site-year, hybrid effects on yield response per unit of water (WP and IWP) varied depending on site-year and irrigation level (Table 3; significant three-way interaction). Producing higher yield under the same amount of total water supply (rain + irrigation) will inevitably lead to increase in WP (Eq. 1). Thus, in terms of hybrid performance, increase in WP represents a relative improvement in the water productivity of the cropping system due to hybrid selection. This is not necessarily the case with IWP, which only accounts for yield difference between irrigated and dryland yield for the amount of irrigation water applied (Eq. 2). The IWP does, however, provide an insight on how efficiently individual hybrids utilized irrigation water in a given environment. 

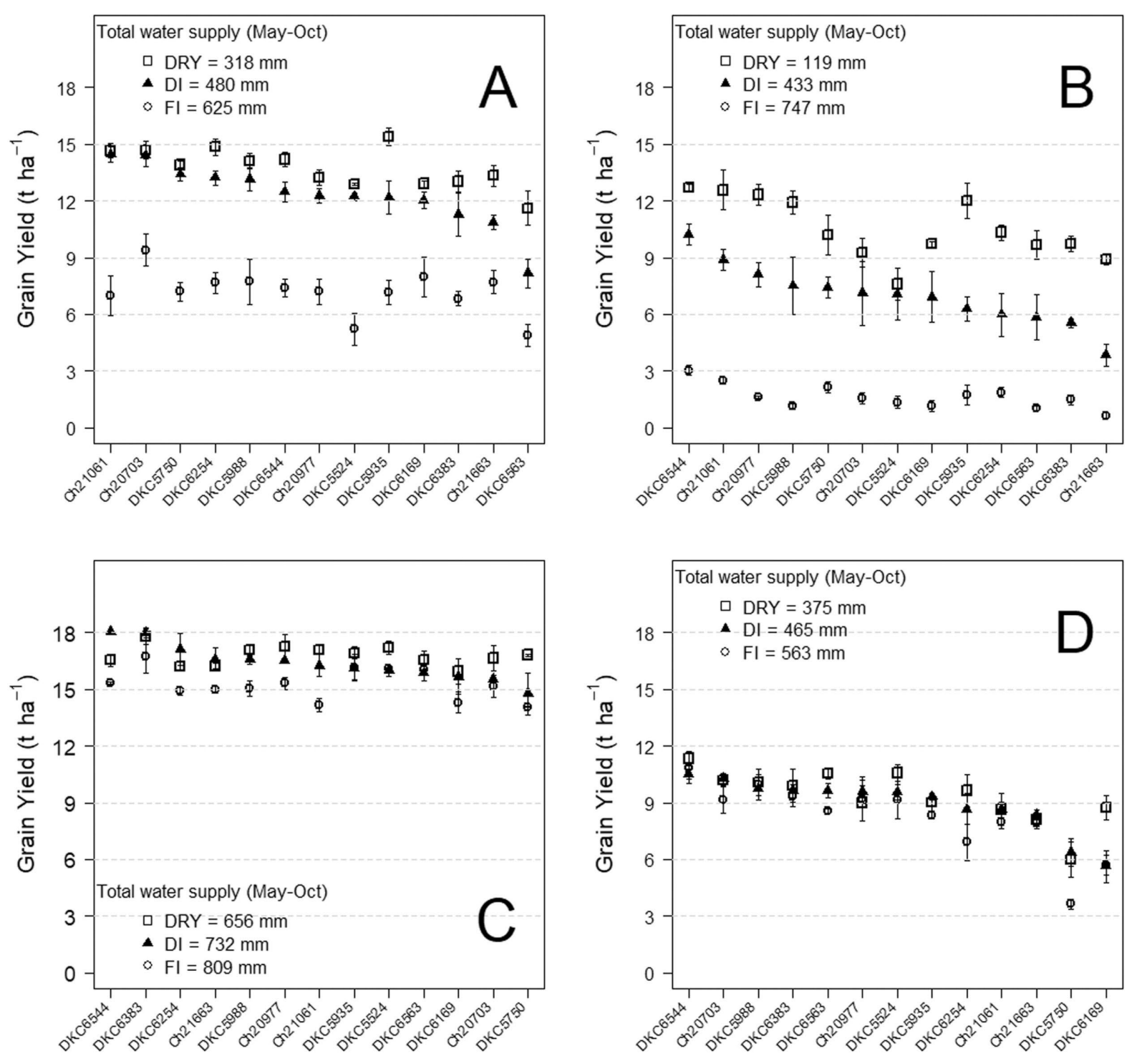

Fig. 2. Mean \pm standard error bars (SE) for grain yield of 13 maize hybrids under dryland (DRY), deficit (DI) and full irrigation (FI) treatment ranked by the best performing hybrid under DI in field experiments at Brule 2011 (A), Brule 2012 (B), Gothenburg 2010 (C), and Gothenburg 2011 (D).

The hybrid WP performance was not affected by irrigation at Brule-2010 (normal year) and Brule-2011 (drought year), as indicated by lack of significant irrigation by hybrid interaction (Table 3). The irrigation by hybrid interaction was significant for WP at Gothenburg-2010 when growing season rainfall was above-average, and at Gothenburg-2011 when maize yield was negatively affected by the windstorm 

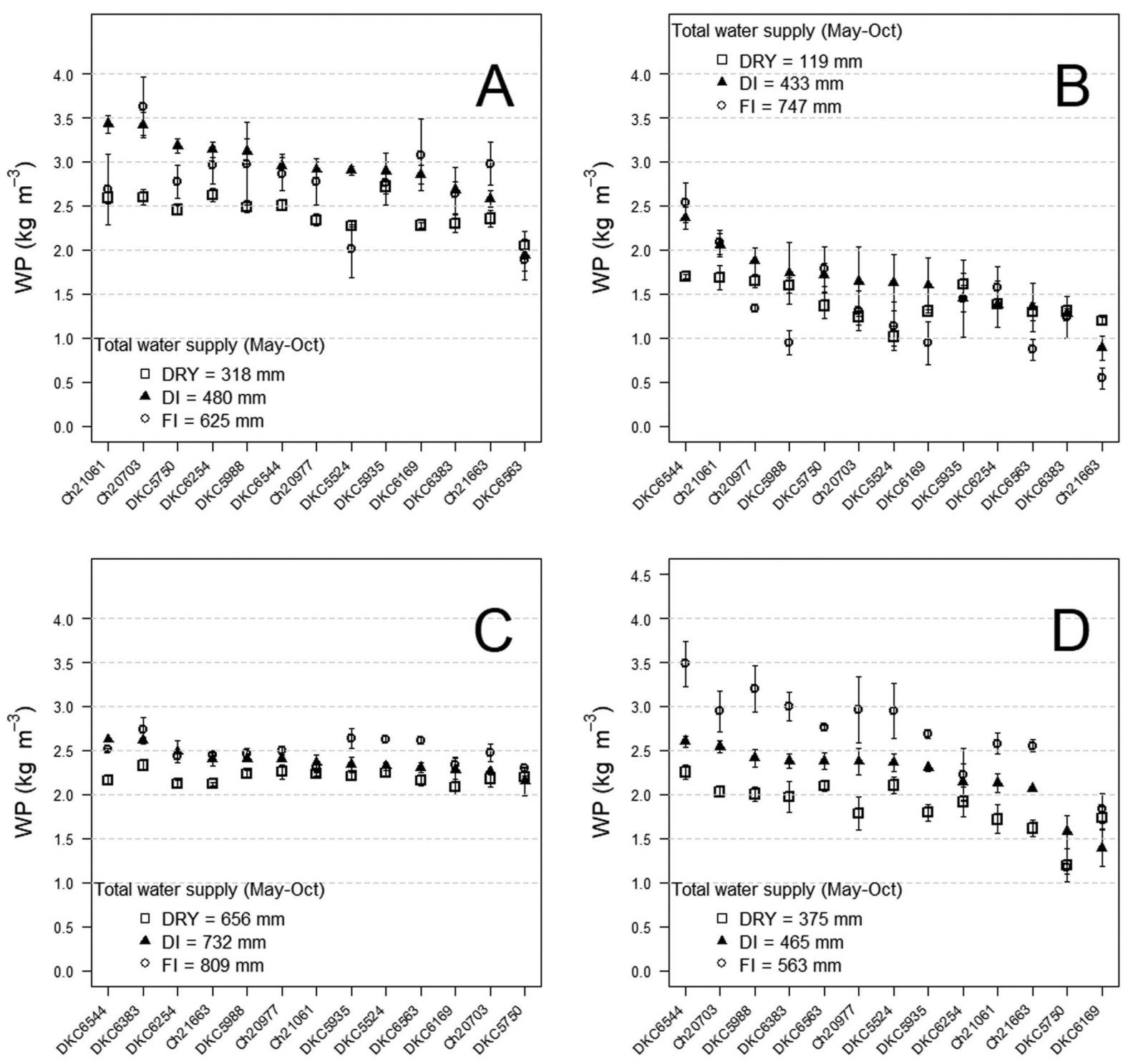

Fig. 3. Mean \pm standard error bars (SE) for water productivity (WP) of 13 maize hybrids under dryland (DRY), deficit (DI) and full irrigation (FI) treatment ranked by the best performing hybrid under DI in field experiments at Brule 2011 (A), Brule 2012 (B), Gothenburg 2010 (C), and Gothenburg 2011 (D).

(Table 3). While in most cases selecting the hybrid with the best overall yield also led to an increase in WP, each site-year had some deviations from the general trend where hybrids WP performance were affected by irrigation treatments (Fig. 2). In a normal year (i.e. at Brule-2011), hybrids Ch20703 and Ch21061 had similar yield and WP under DI and FI and were the overall best performers, but the former had a significant 
yield (2.4 $\mathrm{t} \mathrm{ha}^{-1} ; \mathrm{p}$ value 0.0071 ) and WP (0.94 $\mathrm{kg} \mathrm{m}^{-3}$; $\mathrm{p}$ value 0.001 ) advantage under DRY (Table 3, Figs. 1 and 2). During the drought year at Brule-2012 the top two performing hybrids, DKC6544 and CH21061, had similar yield and WP under FI, while the former performed significantly better ( $p$ value < 0.05) under both DRY and DI (Figs. 1 and 2). In a wet year at Gothenburg-2010, all hybrids performed similarly under FI ( $p$ value for hybrid effects 0.1872 ), whereas significant differences were observed between hybrids under DRY and DI ( $p$ value for hybrid effect $<0.05)$. For example, DKC6544 grown under DI had the highest overall yield (18.1 $\mathrm{t} \mathrm{ha}^{-1}$ ) and WP (2.62 $\mathrm{kg} \mathrm{m}^{-3}$ ), but many other hybrids performed as well or better under DRY and FI (Fig. 3). Due to negative effects of DI and FI on yield at Gothenburg-2011 (i.e. increase in ear drop), all evaluated hybrids had higher WP under DRY.

The reduction in total water supply (rain + irrigation) led to a wider range of hybrid WP and IWP across all environments. The range of hybrid WP in a normal year (i.e. Brule-2011) was $1.9-3.6 \mathrm{~kg} \mathrm{~m}^{-3}$ under DRY, 1.9-3.4 $\mathrm{kg} \mathrm{m}^{-3}$ under DI, and 2.1-2.7 $\mathrm{kg} \mathrm{m}^{-3}$ under FI, with differences between the best and the worst hybrid WP performance being $1.7,1.5$, and $0.7 \mathrm{~kg} \mathrm{~m}^{-3}$ under DRY, DI and FI, respectively. Similar trend occurred in a drought year (i.e. Brule-2012) while much less variation was observed in a wet year (i.e. Gothenburg-2010). At Gothenburg-2011, where the wind storm had minimal impact on DRY yield ( $\sim 5 \%$ yield reduction), WP varied significantly depending on the hybrid, ranging from 1.2 to $3.5 \mathrm{~kg} \mathrm{~m}^{-3}$ and providing up to $89 \%$ difference in WP between the best (45\% above average) and the worst (34\% below average) performing hybrid (Fig. 3). Similar to WP, the hybrid IWP was higher in value and wider in range under DI (Fig. 4). Among the 13 hybrids evaluated in this study, 12, 10, 8, and 10 hybrids had higher IWP under DI at Brule-2011, Brule-2012, Gothenburg-2010, and Gothenburg-2011, respectively. The difference between IWP of the best and worst performing hybrid under DI and FI was, respectively, 2.7 and $1.1 \mathrm{~kg} \mathrm{~m}^{-3}$ at Brule-2011, 1.3 and $0.7 \mathrm{~kg} \mathrm{~m}^{-3}$ at Brule-2011, 3.7 and $1.5 \mathrm{~kg} \mathrm{~m}^{-3}$ at Gothenburg-2010, and 5.9 and $2.6 \mathrm{~kg} \mathrm{~m}^{-3}$ at Gothenburg-2011. The negative IWP values were noted at Gothenburg-2010 (wet year) and Gothenburg-2011 (wind storm), suggesting that damaging impact of irrigation on harvestable yield in these environments can be more pronounced with certain hybrids. 

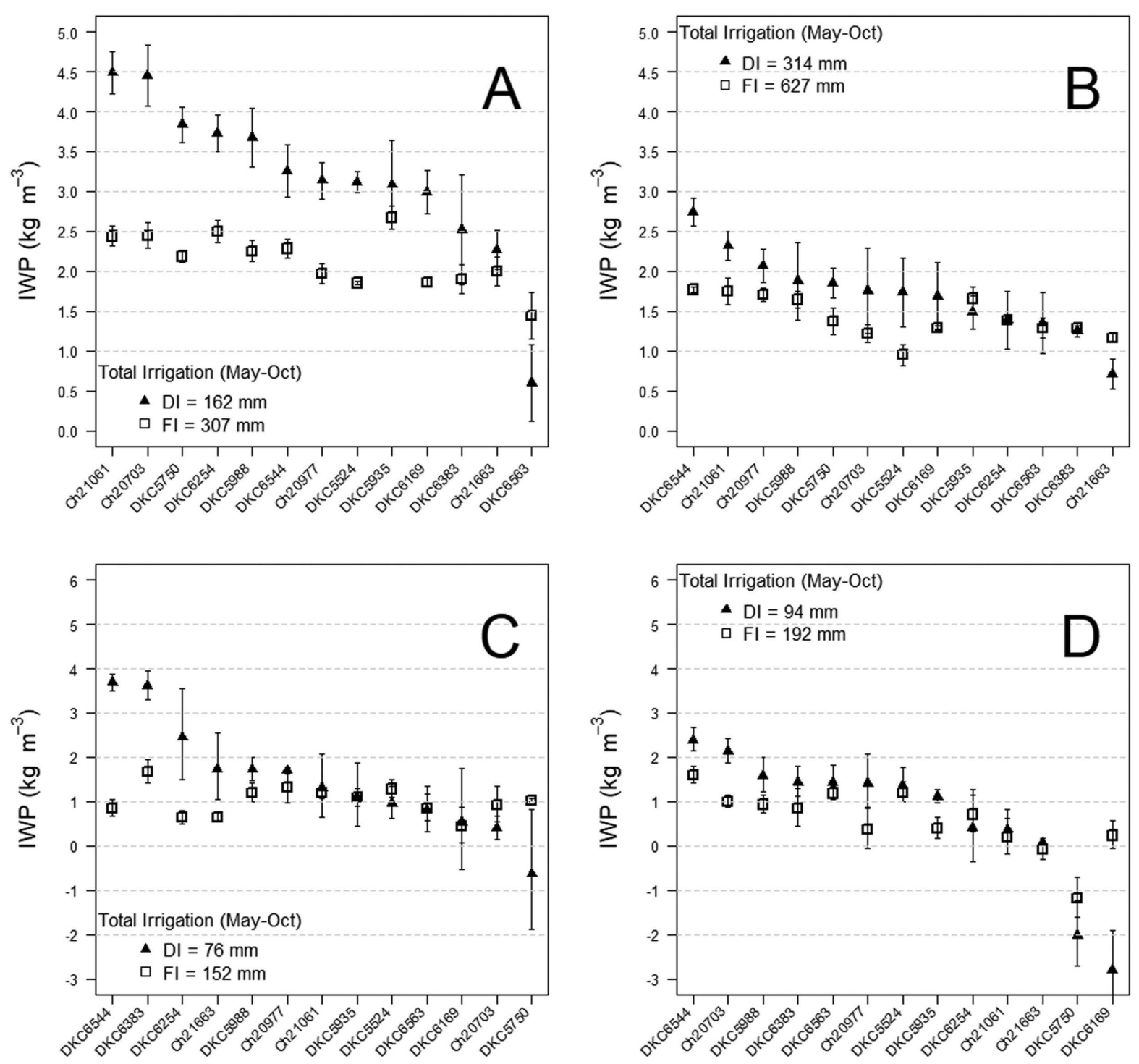

Fig. 4. Mean \pm standard error bars (SE) for irrigation water productivity (IWP) of 13 maize hybrids under dryland (DRY), deficit (DI) and full irrigation (FI) treatment ranked by the best performing hybrid under DI in field experiments at Brule 2011 (A), Brule 2012 (B), Gothenburg 2010 (C), and Gothenburg 2011 (D).

\section{Discussion}

In a very broad sense, the scope of this research was to identify the range of yield and efficiency values across the range of semiarid climatic conditions (e.g. drought, normal, and wet) and irrigation treatments (DRY, DI, and FI) to help growers and regulators assess production and economic 
consequences of water allocations and other regulatory policies in areas with declining groundwater resources. The assessment included evaluation of thirteen hybrids, which in turn caused tremendous variations in yield, WP, and IWP responses. The complexity of genetics $x$ management $\mathrm{x}$ environment ( $\mathrm{G} \times \mathrm{M} \times \mathrm{E}$ ) outcomes found in this manuscript can, therefore, represent different impacts to farmers, policy makers and researchers. An attempt will be made to highlight those differences and discuss when and where information found in this research may be useful.

Large differences in seasonal rainfall observed in this study (119-656 $\mathrm{mm}$ ) caused irrigation requirements to range between 152 and $627 \mathrm{~mm}$ depending on site-year, and allowed an assessment of DI under a wide range of water stress that could exist in water limiting environments. DI with $50 \%$ less water than FI caused yield reduction of as much $33 \%$ in a dry, $11 \%$ in a normal, and $2 \%$ in a wet year. From a strictly economic perspective, the value of DI will, therefore, largely depend on the pumping cost (i.e. production input), yield penalty that resulted from reduced irrigation, and maize grain market price. For the illustration purposes, assume $\$ 0.09$ ha- $\mathrm{m}^{-1}$ pumping cost that includes repairs, operator labor, and energy for a 50 ha pivot irrigation system that pulls water from 40 $m$ depth and operates on a $250 \mathrm{kPa}$ system pressure using an electric pump. A maize grain market price of U.S. $\$ 0.14 \mathrm{~kg}^{-1}$, which was an average closing price of maize in U.S. in 2019, will also be assumed. Based on the reduction in irrigation water consumption and yield penalties observed with DI in this study, marginal net return for maize under DI (i.e. $50 \%$ of FI) decreased by U.S. $\$ 80-217$ ha $^{-1}$ in dry to normal year and increased by U.S. $\$ 9$ in a year with a well above-average seasonal rainfall. While acknowledging that variations in pumping costs and maize grain market price can produce a different outcome, farmer's willingness to adopt DI, when irrigating to FI requirement is possible, is unlikely due to high risk of severe yield/profit losses. Other researchers also found that FI is the most profitable long-term strategy under non-water-limiting conditions (Kisekka et al., 2016; Payero et al., 2008; Rudnick et al., 2016), assuming sound economic and environmental principles of irrigation water management (Geerts and Raes, 2009). On the other hand, increase in potential water losses from practicing FI cannot be neglected. According to Grassini et al. (2011), farmer's perceptions of the risk associated with water stress often resulted in a tendency to over-irrigate. The authors observed that $55 \%$ of the fields evaluated in the study supplied 
irrigation above the full irrigation requirement, suggesting that switching surface systems to pivot irrigation, improving irrigation scheduling, and adaptation of conservation tillage can lead to as much as $32 \%$ reduction in irrigation withdrawals while causing minimum yield penalties (Grassini et al., 2011). In conclusion, increasing farmers' awareness on the impact of excessive irrigation on profitability and groundwater sustainability may be a leading obstacle towards improvements in water conservation in areas where FI is practiced as a long-term irrigation management strategy.

In many parts of the semiarid High Plains, irrigation water is limited due to load management (i.e. shutting off electrical irrigation pumps due to overload in a power system), pumping regulations, light textured soils and or low well capacities, and DI must be used in some form. Value of DI to a farmer will depend on the implementation of strategies that increase the efficiency of applied irrigation (Lilienfeld and Asmild, 2007). In this study, decreasing total irrigation depth by approximately $50 \%$ (i.e. DI) caused a significant 22-47\% increase in IWP, with differences between DI and FI being more pronounced with the increase in seasonal rainfall. Managing irrigation to meet the full crop ET demand includes certain risks associated with increase in water losses such as evaporation, runoff and deep percolation (Geerts and Raes, 2009). As those water losses are more likely to occur with increase in total water supply, IWP tends to decrease sharply with irrigation (Payero et al., 2008). In a drier environment, water losses are reduced and IWP is often maintained or slightly decreased under FI. Spurgeon and Yonts (2013) observed $1.5 \mathrm{t} \mathrm{ha}^{-1}$ yield reduction in maize under $75 \%$ FI while observing no difference in IWP, which is similar to the results observed at Brule-2012 (drought year) in this study. To minimize the yield penalties under DI, farmers must acquire higher knowledge of crop response to drought stress and better understand how variability in weather, soil and crop management factors influence IWP (Geerts and Raes, 2009). Utilizing widely-available tools and technologies that allow timely and accurate assessment of available water supply and crop-water needs prior to making each irrigation decision can be very valuable (Lo et al., 2019; Rudnick et al., 2019). Adopting novel approaches that are conducive to both amount and timing of input applications throughout the season, such as input requirement range, may lead to an improved decision making, near maximum profitability, and near optimal input efficiency (Lo et al., 2019). 
In a context of many different approaches to DI, it is appropriate to conclude that ineffective irrigation would disregard the importance of yearto-year and site-specific variability of crop growing conditions and its impact on grain yield response to irrigation (Rudnick et al., 2019).

Hybrid selection is a very distinctive, one-time, farm management decision typically based on a combination of previous experiences, public and private results from regional hybrid performance trials, and/or recommendations from area farmers and local seed dealers. Once crop is planted, farmers make a series of in-season agronomic and irrigation management decisions to maximize yield and profit of the selected hybrid. Hybrid selection, therefore, has a profound effect on crop production as a unique component of $\mathrm{G} \times \mathrm{E} \times \mathrm{M}$ interaction that determines (and often limits) the yield potential before the season starts and before other important in-season management decisions (e.g. fertility or irrigation) are made. Despite the multitude of choices, selecting the hybrid adapted to the semiarid climate of western Nebraska has never been more challenging due to: (1) limited multi-year hybrid performance data, (2) fast cycling of hybrids on a market, and (3) variable weather patterns. Large discrepancy in the expected yield for maize grown under a typical DRY (4-10 t ha-1) and/or FI (12-18 t ha-1) environment narrowed down hybrid recommendations based either on a drought tolerance (i.e. DRY) or "responsiveness to high-intensity management" (i.e. FI). This study, however, clearly illustrates that DRY weather conditions in semiarid western Nebraska can also be arid (162 mm at Brule-2012) and humid (656 $\mathrm{mm}$ at Gothenburg-2010) extending the range of expected yield to 1.6$16 \mathrm{t} \mathrm{ha}^{-1}$ and dramatically influencing yield potential and irrigation requirements. Nevertheless, hybrid yield stability in this study was more site- and less weather-specific. Total of 8 hybrids at Brule and 9 hybrids at Gothenburg had similar yield performance regardless of large differences in weather patterns across two year, while only 4 hybrids had similar performance at Brule and Gothenburg in a year with near-average rainfall patterns. Among thirteen hybrids evaluated across four environments, only a few hybrids performed consistently well across all site-years. Guillen-Portal et al. (2003) also recognized yield stability as an important trait for maize hybrids grown in semiarid climates. The authors proposed ranking of the hybrids based on safety-first index that includes average yield performance, variance as a measure of yield stability, and minimum acceptable yield, as defined by input cost, 
income risk attitude, and anticipated grain market price (Guillen-Portal et al., 2003). Testing this concept across 8 dryland and 4 irrigated environments in the Western High Plains, authors reported that heterogeneous maize hybrids (i.e. double crosses), though slightly lower in average yield in the region, had fewer yields on the lower and upper end of the spectrum than homogeneous (i.e. single cross) hybrids (Guillen-Portal et al., 2003). Such hybrids were considered a safer choice under DRY conditions where minimum acceptable yields are less than $2.68 \mathrm{t} \mathrm{ha}^{-1}$ (Guillen-Portal et al., 2003). A more in-depth look at morphophysiological traits of hybrids resilient to wide variations in soil and weather conditions (such as DKC6544 in this study) can provide valuable information to maize breeders and facilitate the genetic improvement in maize hybrids adaptable to semiarid High Plains.

Despite the general trend of hybrid performances (i.e. hybrid ranking) being similar under different irrigation regimes, yield, WP, and IWP were higher in value and wider in range under DI and DRY, suggesting greater impact (both positive or negative) of hybrid selection on crop production in water-limited environments. In this study, maximum yield difference between the hybrids in a wet, normal and drought year was respectively, 1.9, 3.8, a $5.1 \mathrm{t} \mathrm{ha}^{-1}$ under FI, 3.3, 6.3, and 6.4 $\mathrm{tha}^{-1}$ under DI, and 2.7, 2.4, and $4.5 \mathrm{t} \mathrm{ha}^{-1}$ under DRY. Depending on a year and irrigation level, there was as much as $0.7-2.3 \mathrm{~kg} \mathrm{~m}^{-3}$ difference in WP and $0.7-5.9 \mathrm{~kg} \mathrm{~m}^{-3}$ difference in IWP between hybrids, with differences being greater with reduction in total water supply (rain + irrigation). Many other researchers throughout the semiarid regions of the world reported similar findings, validating the hypothesis that genotypic differences in maize hybrids are more likely to be expressed when exposed to some level of water stress (Lorens et al., 1987; Atteya, 2003; Kaman et al., 2011; Aydinsakir et al., 2013; Hao et al., 2015a; Hao et al., 2015b; Al-Naggar et al., 2016; Sabagh et al., 2018). For example, Hao et al. (2015b) reported 6-25\% yield and 9-30\% WP advantage of drought-tolerant hybrid over conventional hybrid across the range of irrigation treatments in Texas High Plains, with increase in yield and WP being proportionally larger under DI. In another Texas High Plains study, WP of two drought-tolerant hybrids was $9.8-11.7 \%$ and $20 \%$ higher than that of a conventional hybrid under 75\% FI and 50\% FI, respectively (Hao et al., 2015a). In a study conducted at Florida, Lorens et al. (1987) found that two hybrids with similar response under optimal irrigation had substantial differences 
in yield and morpho-physiological responses when exposed to water stress. Similar results came out of research studies conducted in Egypt (Atteya, 2003; Al-Naggar et al., 2016), Kenya (Mhike et al., 2012), Turkey (Kaman et al., 2011; El Sabagh et al., 2015; EL Sabagh et al., 2018), Iran (Moradi et al., 2012), and India (Sah et al., 2020). From the economic standpoint, acquiring information regarding site-specific hybrid performance for an approximate level of total water supply can make a substantial difference in net returns. Based on the differences in hybrid performances reported here and aforementioned assumptions regarding maize grain market price $\left(\$ 0.14 \mathrm{~kg}^{-1}\right)$, potential impact of hybrid selection on marginal net return can range from U.S. \$261-714 ha-1 under FI and U.S. \$460-880 ha-1 under DI, with differences being larger in drier environments.

\section{Conclusion}

The results of this research provided an insight on how deficit irrigation and hybrid selection compare and complement each other in terms of implementing strategies to decelerate the declines in groundwater resources while maintaining productivity and profitability of irrigated maize production in semiarid regions around the world. In western $\mathrm{Ne}-$ braska, continuing to irrigate at the current rates will inevitably lead to groundwater withdrawals exceeding recharge. Policy makers (i.e. board of elected farmer representatives) are often confronted with difficult decisions to impose groundwater pumping regulations. While regulatory polices facilitate the adoption of irrigation scheduling tools and technologies that improve irrigation water productivity (IWP), they often lead to irrigating percentage of full maize irrigation requirements (i.e. deficit irrigation) and have minor to no impact on water productivity of the overall cropping system (i.e. water productivity; WP). In semiarid climates, such scenario inevitably leads to a long-term reduction in yield and profit. Unlike deficit irrigation, current study revealed a massive impact of hybrid selection on water productivity (i.e. WP). Depending on the total water supply, as much as $7.2 \mathrm{t} \mathrm{ha}^{-1}$ difference in yield and 3.6 $\mathrm{kg} \mathrm{m}^{-3}$ difference in WP based solely on hybrid selection was observed, with few top-performing hybrids yielding similarly under deficit irrigation and full irrigation in a normal and/or wet year. Furthermore, 
being a one-time decision, economic risks associated with hybrid selection appear to be much greater and less formidable than that of deficit irrigation.

Preserving groundwater resources in semiarid western Nebraska will continue to depend on reductions in groundwater withdrawals. Gradual changes in multiyear water allocation can allow farmers to fine-tune deficit irrigation strategies, implement other water conservation practices (e.g. alternative crop rotations, residue management, etc.), or retire irrigated lands without major economic consequences. In addition to pumping regulations, better understanding of off-season recharge as well as water balance for major land uses in the watershed (e.g. no-till summer fallow, perennial pasture, winter wheat) are needed to develop more comprehensive polices to sustain groundwater resources. From a perspective of an irrigated maize producer, despite groundwater regulatory policies, acquiring knowledge regarding site-specific hybrid performances for an approximate level of total water supply can make a substantial difference in increasing water productivity of the cropping system and ultimately profit.

Acknowledgments We would like to thank a former University of Nebraska-Lincoln (UNL) graduate student Chad Hermeleracht and UNL research manager Jeff Golus for assisting in data collection. We also thank the staff at Bayer's Water Utilization Learning Center at Gothenburg, NE for providing land, machinery, and labor to successfully complete field studies. We also thank Bayer CropScience for funding this project.

Competing Interests The authors have no known competing financial interests or personal relationships that could have appeared to influence the work reported in this paper.

\section{References}

Al-Naggar, A., Atta, M., Ahmed, M., Younis, A., 2016. Influence of deficit irrigation at silking stage and genotype on Maize (Zea mays L.) agronomic and yield characters. J. Agric. Ecol. Res. Int. 7 (4), 1-16. https://doi.org/10.9734/ IAERI/2016/25438

Atteya, A.M., 2003. Alteration of water relations and yield of corn genotypes in response to drought stress. Bulg. J. Plant Physiol. 29 (1-2), 63-76.

Aydinsakir, K., Erdal, S., Buyuktas, D., Bastug, R., Toker, R., 2013. The influence of regular deficit irrigation applications on water use, yield, and quality components 
of two corn (Zea mays L.) genotypes. Agric. Water Manag. 128, 65-71. https://doi. org/10.1016/j.agwat.2013.06.013

Bos, M.G., 1985. Summary of ICID definitions of Irrigation efficiency. ICID Bull. Int. Comm. Irrig. Drain. 34 (1), 28-31.

Bos, Marinus G., 1980. Irrigation efficiencies at crop production level. Int. Comm. Irrig. Drain. ICID 29 (2), 18-24.

Campos, H., Cooper, M., Habben, J.E., Edmeades, G.O., Schussler, J.R., 2004. Improving drought tolerance in maize: a view from industry. Field Crops Res. 90 (1), 19-34. https://doi.org/10.1016/j.fcr.2004.07.003

Cicogna, A., Dietrich, S., Gani, M., Giovanardi, R., Sandra, M., 2005. Use of meteorological radar to estimate leaf wetness as data input for application of territorial epidemiological model (Downy mildew-Plasmopara viticola). Phys. Chem. Earth Parts A B C 30 (1-3), 201-207. https://doi.org/10.1016/j. pce.2004.08.015

Eck, H.V., 1986. Effects of water deficits on yield, yield components, and water use efficiency of irrigated corn. Agron. J. 78 (6), 1035-1040. https://doi.org/10.2134/ agronj1986.00021962007800060020x

El Sabagh, A. Barutçular, C., Saneoka, H., Assessment of Drought Tolerance Maize Hybrids at Grain Growth Stage in Mediterranean Area 9(9) 20154.

English, M., 1990. Deficit irrigation. i: analytical framework. J. Irrig. Drain. Eng. 116 (3), 399-412. https://doi.org/10.1061/(ASCE)0733-9437(1990)116:3(399)

Ertek, A., Kara, B., 2013. Yield and quality of sweet corn under deficit irrigation. Agric. Water Manag. 129, 138-144. https://doi.org/10.1016/j.agwat.2013.07.012

Evett, S.R., Steiner, J.L., 1995. Precision of neutron scattering and capacitance type soil water content gauges from field calibration. Soil Sci. Soc. Am. J. 59 (4), 961968. https://doi.org/10.2136/sssaj1995.03615995005900040001x

Fabeiro, C., 2001. Yield and size of deficit irrigated potatoes. Agric. Water Manag. 12.

Geerts, S., Raes, D., 2009. Deficit irrigation as an on-farm strategy to maximize crop water productivity in dry areas. Agric. Water Manag. 96 (9), 1275-1284. https:// doi.org/10.1016/j.agwat.2009.04.009

Grassini, P., Yang, H., Irmak, S., Thorburn, J., Burr, C., Cassman, K.G., 2011. High-yield irrigated maize in the Western U.S. Corn Belt: II. Irrigation management and crop water productivity. Field Crops Res. 120 (1), 133-141. https://doi.org/10.1016/j. $\underline{\text { fcr.2010.09.013 }}$

Guillen-Portal, F.R., Russell, W.K., Baltensperger, D.D., Eskridge, K.M., D'Croz-Mason, N. E., Nelson, L.A., 2003. Best types of maize hybrids for the western high plains of the USA. Crop Sci. 43 (6), 2065-2070. https://doi.org/10.2135/cropsci2003.2065

Haacker, E.M.K., Kendall, A.D., Hyndman, D.W., 2016. Water level declines in the high plains aquifer: predevelopment to resource senescence. Groundwater 54 (2), 231-242. https://doi.org/10.1111/gwat.12350

Hao, B., Xue, Q., Marek, T.H., Jessup, K.E., Becker, J., Hou, X., Xu, W., Bynum, E.D., Bean, B.W., Colaizzi, P.D., Howell, T.A., 2015a. Water use and grain yield in droughttolerant corn in the Texas high plains. Agron. J. 107 (5), 1922-1930. https://doi. org/10.2134/agronj15.0133 
Hao, Baozhen, Xue, Q., Marek, T.H., Jessup, K.E., Hou, X., Xu, W., Bynum, E.D., Bean, B. W., 2015b. Soil water extraction, water use, and grain yield by drought-tolerant maize on the Texas High Plains. Agric. Water Manag. 155, 11-21. https://doi. org/10.1016/j.agwat.2015.03.007

Irmak, S., Payero, J.O., Martin, D.L., 2005. Using Modified Atmometers (ET gage) for Irrigation Management. University of Nebraska-Lincoln. NebGuide G1579. https://extensionpublications.unl.edu/assets/pdf/g1579.pdf

Kaman, H., Kirda, C., Sesveren, S., 2011. Genotypic differences of maize in grain yield response to deficit irrigation. Agric. Water Manag. 98 (5), 801-807. https://doi. org/10.1016/j.agwat.2010.12.003

Kisekka, I., Aguilar, J.P., Rogers, D.H., Holman, J., O’Brien, D.M., Klocke, N., 2016. Assessing deficit irrigation strategies for corn using simulation. Trans. ASABE 59 (1), 303-317. https://doi.org/10.13031/trans.59.11206

Kranz, W.L., Irmak, S., van Donk, S.J., Yonts, C.D., Martin, D.L., 2008. Irrigation Management For Corn. University of Nebraska-Lincoln. NebGuide G1850. https:// extensionpublications.unl.edu/assets/pdf/g1850.pdf

Lamphear, C., 2003. Economic Importance of Irrigated Agriculture 2003, Nebraska Policy Institute, 2005. https://digitalcommons.unl.edu/econfacpub/101

Lilienfeld, A., Asmild, M., 2007. Estimation of excess water use in irrigated agriculture: a data envelopment analysis approach. Agric. Water Manag. 94 (1-3), 73-82. https://doi.org/10.1016/j.agwat.2007.08.005

Lo, T.H., Rudnick, D.R., Burr, C.A., Stockton, M.C., Werle, R., 2019. Approaches to evaluating grower irrigation and fertilizer nitrogen amount and timing. Agric. Water Manag. 213, 693-706. https://doi.org/10.1016/j.agwat.2018.11.010

Lorens, F., Bennett, J.M., Loggale, L.B., 1987. Differences in drought resistance between two corn hybrids II. Component Analysis and Growth Rates. Agronomy Journal, 79 (5), 808-813. https://doi.org/10.2134/agronj1987.00021962007900 $\underline{050010 x}$

McGuire, V. , 2017 , Water-Level and Recoverable Water in Storage Changes, High Plains Aquifer, Predevelopment to 2015 and 2013-2015 (Scientific Investigations Report). U.S. Geological Survey.

Marouelli, W.A., Silva, W.L.C., 2007. Water tension thresholds for processing tomatoes under drip irrigation in Central Brazil. Irrig. Sci. 25 (4), 411-418. https://doi. org/10.1007/s00271-006-0056-6

Mhike, X., Patrick, O., Cosmos, M., Thokozile, N., 2012. Validation of the use of secondary traits and selection indices for drought tolerance in tropical maize (Zea mays L.). African J. Plant Sci. 6 (2) https://doi.org/10.5897/AJPS11.179

Moradi, H., Akbari, G.A., Khorasani, S.K., Ramshini, H.A., 2012. Evaluation of drought tolerance in corn (Zea mays L.) new hybrids with using stress tolerance indices. Eur. J. Sustain. Dev. 1 (3), 543. https://doi.org/10.14207/ejsd.2012.v1n3p543

Nebraska Farm Bureau, 2012. Economic Impact of the Ability of Nebraska Agriculture to Irrigate-The Case of 2012. Nebraska Farm Bureau. http://www.decisioninnovation.com/webres/File/docs/Nebraska\%20Irrigation\%20Economic $\% 20$ Impact $\% 20$ Study.pdf 
Oweis, T., Pala, M., Ryan, J., 1998. Stabilizing rainfed wheat yields with supplemental irrigation and nitrogen in a Mediterranean climate. Agron. J. 90 (5), 672-681. https://doi.org/10.2134/agronj1998.00021962009000050017x

Payero, J.O., Tarkalson, D.D., Irmak, S., Davison, D., Petersen, J.L., 2008. Effect of irrigation amounts applied with subsurface drip irrigation on corn evapotranspiration, yield, water use efficiency, and dry matter production in a semiarid climate. Agric. Water Manag. 95 (8), 895-908. https://doi. org/10.1016/j.agwat.2008.02.015

Rudnick, D., Irmak, S., Ferguson, R., Shaver, T., Djaman, K., Slater, G., Bereuter, A., Ward, N., Francis, D., Schmer, M., Wienhold, B., Van Donk, S., 2016. Economic Return versus Crop Water Productivity of Maize for Various Nitrogen Rates under Full Irrigation, Limited Irrigation, and Rainfed Settings in South Central Nebraska. J. Irrig. Drain Eng., 04016017 https://doi.org/10.1061/(ASCE) $\underline{\text { IR.1943-4774.0001023 }}$

Rudnick, D.R., Irmak, S., West, C., Chávez, J.L., Kisekka, I., Marek, T.H., Schneekloth, J. P., Mitchell McCallister, D., Sharma, V., Djaman, K., Aguilar, J., Schipanski, M.E., Rogers, D.H., Schlegel, A., 2019. Deficit irrigation management of maize in the high plains aquifer region: a review. JAWRA J. Am. Water Resour. Assoc. 55 (1), 38-55. https://doi.org/10.1111/1752-1688.12723

Sabagh, Ayman E.L., Hossain, A., Barutçular, C., Khaled, A.A., Fahad, S., Anjorin, F.B., Islam, M.S., Ratnasekera, D., Kizilgeçi, F., Yadav, G.S., Yildirım, M., Konuskan, O.,

Saneoka, H., 2018. Sustainable Maize (Zea mays L.) production under drought stress by understanding its adverse effect, survival mechanism and drought tolerance indices. J. Exp. Biol. Agric. Sci. 6 (2), 282-295. https://doi.org/10.18006/2018.6( 2).282.295

Sah, R.P., Chakraborty, M., Prasad, K., Pandit, M., Tudu, V.K., Chakravarty, M.K., Narayan, S.C., Rana, M., Moharana, D., 2020. Impact of water deficit stress in maize: Phenology and yield components. Scientific Reports 10 (1). https://doi. org/10.1038/s41598-020-59689-7

SAS Institute, 2013. Base SAS 9.4 procedures guide. SAS Institute Inc. http://www. books $24 \times 7 . \mathrm{com} / \mathrm{marc}$.asp? bookid $=58442$

Shaver, T., 2014. Nutrient Management for Agronomic Crops in Nebraska. University of Nebraska-Lincoln. EC155. https://extensionpublications.unl.edu/assets/pdf/ ec155.pdf

Singh, J., Lo, T., Rudnick, D.R., Dorr, T.J., Burr, C.A., Werle, R., Shaver, T.M., MuñozArriola, F., 2018. Performance assessment of factory and field calibrations for electromagnetic sensors in a loam soil. Agric. Water Manag. 196, 87-98. https:// doi.org/10.1016/j.agwat.2017.10.020

Spurgeon, E.W., Yonts, D.C., 2013. Water productivity of corn and dry bean rotation on very fine sandy loam soil in western Nebraska. Appl. Eng. Agric. 29 (6), 885892. https://doi.org/10.13031/aea.29.9872

Stewart, B.A., Musick, J.T., Dusek, D.A., 1983. Yield and water use efficiency of grain sorghum in a limited irrigation-dryland farming system. Agron. J. 75 (4), 629634. https://doi.org/10.2134/agronj1983.00021962007500040013x 
Ünlü, M., Kanber, R., Şenyigit, U., Onaran, H., Diker, K., 2006. Trickle and sprinkler irrigation of potato (Solanum tuberosum L.) in the middle Anatolian region in Turkey. Agric. Water Manag. 79 (1), 43-71. https://doi.org/10.1016/j. agwat.2005.02.004

Van Duivenbooden, N., Pala, M., Studer, C., Bielders, C.L., Beukes, D.J., 2000. Cropping systems and crop complementarity in dryland agriculture to increase soil water use efficiency: a review. NJAS Wagening. J. Life Sci. 48 (3), 213-236. https://doi. org/10.1016/S1573-5214(00)80015-9

Xue, Q., Zhu, Z., Musick, J.T., Stewart, B.A., Dusek, D.A., 2003. Root growth and water uptake in winter wheat under deficit irrigation. Plant Soil 257 (1), 151-161. https://doi.org/10.1023/A:1026230527597

Yenesew, M., Tilahun, K., 2009. Yield and water use efficiency of deficit-irrigated maize in a semi-arid region of Ethiopia. Afr. J. Food, Agric. Nutr. Dev. 9 (8) https:// doi.org/10.4314/ajfand.v9i8.48403 